\title{
Jomatt \\ Public tourism policies in the Brazilian Amazon: Participation and networks
}

\author{
Kassia Suelen Farias, Silvio Lima Figueiredo*
}

ABSTRACT
$\begin{aligned} & \text { Keywords: } \\ & \text { Tourism, } \\ & \text { Public policy, } \\ & \text { Participation } \\ & \text { elucidate the concept of participation, networks and public policies so that the mechanisms of their } \\ & \text { organization in this region can be understood. This work is an excerpt from the dissertation entitled } \\ & \text { "Tourism governance on Ilha do Marajo, Pará, Brazil: An analysis of the relationship networks } \\ & \text { established in public tourism policies" (Farias, 2018). This analysis uses an interdisciplinary approach } \\ & \text { in tourism, seeking to interpret it from theoretical perspectives on participation in public policies. The } \\ & \text { study follows several steps which in the end could be connected and interpreted based on the assumptions } \\ & \text { of qualitative research. The bibliographical deepening, documentary analysis, the elaboration and } \\ & \text { application of semi-structured interviews directed the study to reach the proposed objective. Thus, the } \\ & \text { analysis revealed that the participation of agents in the decision-making process in tourism does not aim } \\ & \text { to disregard the State, but seeks to confirm the importance that institutions represent. Some examples } \\ & \text { are civil initiatives and organizations such as the Women's Association of Pesqueiro (Associação das } \\ & \text { Article History: }\end{aligned}$
Submitted: 07.05.2021
Accepted: 12.12.2021

Doi: https://doi.org/10.31822/jomat.2021-SP-1-53

\section{Introduction}

The Amazon region was the scene of regional development processes allied to public policies throughout the end of the 20th century and in the first two decades of the 21st century, which guaranteed, at least in intention, the benefits of this development for its population, and therefore for the whole country. Thus, the region appears as a paradigm for attempts at regional development and sectorial public policies. In recent decades, there is a need to reflect on the characteristics of these developmental processes and their criticisms based on incorporating sustainability and related concepts. At the same time that there is a need to develop the region, tourism also begins to appear in regional plans as a vector of development based on its "multiplier effects" and the low investment capacity for its practice.

This picture had several characteristics of its own in many municipalities and Amazonian states. There was a growth in the tourism sector in the state of Pará and more precisely on Ilha do Marajó, mainly from investments by businessmen and local farmers, who built hotels and inns in the early 1980s and prepared their large farms to welcome visitors.

In addition to the increase in investments and the flow of tourists and their diversification, national tourism policies relatively contributed to adv ance the increase and growth of this sector in Marajó. The ideas of sustainable development of tourism and ecotourism practices are inserted with these policies, much more as a marketing appeal: without much to do with the essences of these activities (Figueiredo, 1999). In addition, social participation is also inserted as an attempt to reframe the conduct of public tourism planning for the region, while meeting the demands of the international market and even the pressures of civil society.

Advancing the ideas of participation and decentralization (already dominant in the late 1990s), the creation of the Ministry of Tourism (MTUR) in 2003 created a favorable environment

\begin{tabular}{cl}
\hline *Corresponding Author & \\
\hline Kassia Suelen Farias: & $\begin{array}{l}\text { Master, Federal University of Para, Belém, Pará Brazil, Email: kassiasfarias@gmail.com, } \\
\text { Orcid Id: 0000-0002-7876-3652 (D }\end{array}$ \\
\hline Silvio Lima Figueiredo: & $\begin{array}{l}\text { Prof. Dr., Federal University of Para, Belém, Pará Brazil, Email: silviolimafigueiredo@ @mail.com, } \\
\text { Orcid Id: 0000-0002-6810-1639 iD }\end{array}$ \\
\hline $\mathrm{CC})(\mathrm{F})$ &
\end{tabular}


for elaborating the Tourism Regionalization Program - Brazilian Routes (Programa de Regionalização do Turismo - Roteiros do Brasil PRT), based on the guidelines contained in the National Tourism Plan (Plano Nacional de Turismo - PNT) 2003-2007. The program implemented the public tourism policy in a decentralized and regionalized way, and the creation and strengthening of the groups that represented the tourism productive chain stand out among its objectives.

Some previously conceived studies address the difficulty of directly or indirectly articulating between those involved in the tourism production chain, understanding that this is one of the main causes of limited performance of this activity in the State of Pará as a whole, and specifically in Marajó (Figueiredo, 1999; Nóbrega, 2012; Nóbrega; Figueiredo, 2014; Farias; Figueiredo, 2015, Nascimento, 2015). Although tourism policies henceforth based on sustainability and participation have been aimed at the region based on official discussions, it has been difficult to promote economic growth along with environment preservation, not to mention promoting the autonomy of local populations and processes which lead to greater social participation, whether in the creation of political instruments or their implementation.

The organization and participation of civil society in the debates and instruments conducted by the State are considered essential, as the concept of the State should not be limited to the debate of its costs and governmental devices, but its institutional structure, interests, disputes and actors involved, income distribution, development of inclusion actions, social justice and the continuous preservation of citizenship must all be taken into account. Therefore, the different actors should be included in this process, as they are at the same time "sensors" who are able to identify the effectiveness of such public policies, as well as "actors" capable of performing in a unique way in conducting and implementing policies and the conduct of the State.

Therefore, the objective of this study was to analyze the tourism network of Marajó, PA, Brazil, in seeking to elucidate the concept of participation, networks and public policies in the tourism network in order to understand the different tourism organization processes present in this region. The analysis comes from a part of the dissertation entitled "Tourism governance on Ilha do Marajó, Pará, Brazil: An analysis of the relationship networks established in public tourism policies" ${ }^{1}$ (Farias, 2018). An interdisciplinary approach to tourism was implemented in seeking to interpret it from theoretical perspectives on participation in public policies. The study followed several steps which in the end could be connected and interpreted based on the assumptions of qualitative research. The bibliographical deepening, documentary analysis, and elaboration and application of semi-structured interviews directed the study to reach the proposed objective. The analysis revealed that the participation of agents in the decision-making process of tourism does not aim to disregard the State, but seeks to confirm the importance that institutions represent. Some examples include civil initiatives and organizations such as the Women's Association of Pesqueiro (Associação das Mulheres do Pesqueiro - ASMUPESQ), as evidenced in the study.

\section{Networks and public policies}

Network analysis is understood as a useful tool to identify the connections and links represented between actors in tourism public policies (Wray, 2009; Beaumont, Dredge, 2010; Baggio; Scott; Cooper, 2010), and has been widely used under different approaches in scientific studies, whether in sociology or anthropology with analyzes built from a qualitative approach (Barnes, 1987), or in mathematics or information technology where quantitative aspects are more present. Studies conducted by Baggio, Scott and Cooper (2010) can be mentioned as an example.

As Fleury (2002) clarifies, the analysis of networks has been deployed to: 1) understand the relationship between interdependent actors; 2) redirect the object of analysis from the individual actor to interactions with a whole; and 3) indicate the political change of society in response to political/social problems. Thus, networks from a social viewpoint are understood as a structure which connects people and establishes interdependent links, thereby highlighting organizational life (Wray, 2009) instead of individual aspects or group attributes. This allows us to understand the importance of each individual 
in the network, as well as the influence, preference or distribution of powers.

The networks change according to the social and institutional issues and the historical context of each place, also making it possible to understand the characteristics of the territory as they are made up of "elements which differ over time" (Haesbaert, 2019 , p. 293). When analyzing the "network society", Castells (2019) emphasizes that even though networks arise in a process of technological innovations, they take place in a field of communication and are not restricted to technological perceptions, but necessarily depend on the way in which these technologies are captured and made dynamic in the structures of society. That is why there is "synergistic interaction between technological discovery and social evolution" (Castells, 2019, p. 36), which is necessary to understand their specificities as a social organization.

For Fleury (2002) and Schneider (2005), the analysis of networks enabled us to understand the transformations of political-administrative structures with new concepts that express recognizing the complexity of the State and society in order to understand the diversification of actors and resources needed in a given problem. Such resources excel in establishing connections and organizing new social structures, being important for achieving policies, and therefore are able to guarantee the organization of dispersed resources and respond to the problems of public policies (Fleury, 2002).

The networks are also presented as a possibility for organizing civil society, for implementing and articulating social movements in confronting concrete problems. In the new sociopolitical scenario which started in the 1990s in Latin America, new social struggles have been formed and movements and organizations have started to establish themselves in networks which unfold and are articulated by the same social, economic, cultural, political, religious problems, etc., which provide new connotations to the structure of civil society and its relationship with the State (Gohn, 2013). According to Gohn (2013), at that time the networks would enable understanding sociocultural diversity and its articulation with political issues, without falling into a totalizing and homogenizing vision of these relationships.

Based on Enne (2004), applying the concept of networks in social sciences began in the 1950s, mainly with the studies carried out by John
Arundel Barnes (1987), who used the idea of social networks to understand how individuals used personal kinship and friendship ties in a community in Norway. Barnes (1987) proposed to analyze "non-political" local subjects and institutions and demonstrated their importance in relation to political institutions, such as parliaments, parties, elections and diplomacy. Furthermore, he identified the indispensability of the concept of networks to analyze the internal structures of groups and individuals, in addition to understanding that many political processes derive from institutions that fulfill non-political functions, making it essential to analyze these structures to understand the political realities of the place. Thus,

[...] to adopt the perspective of politics which is implicit in expressions such as academic politics, sports politics, church politics, etc. We should look at it from this perspective, wherever we can find those processes through which individuals and groups try to mobilize support for their various goals and, in that sense, influence the attitudes and actions of their followers (Barnes, 1987, p.160).

Although he recognizes other ways of identifying social groups, Barnes (1987) clarifies that the use of this concept in research performed in Anthropology (for example), is due to the possibility of describing social processes which are established in connections that are beyond the visible limits of a group, which helps to understand if there is a leadership and who the followers are.

In more recent analyses, Schneider (2005) points out three factors that were essential for the emergence of networks: 1) collective mobilization around greater effectiveness of policy implementations; 2) the dynamics of social science studies; and 3) the emergence of new technological and knowledge processes. For the author, participation is related to the symbolic logic of each social actor, whether individual or collective, and these processes are in tune with the precepts of the networks. The author points out that individuals are at the same time sensors which capture the political system and intelligent actors who decide on this system. Based on the concept of "institutional cybernetics", Schneider (2005) reinforces that public policy is not an exclusive matter of a governmental hierarchy, but is located in a complex interference zone which involves collective and private matters that integrate and cooperate in a network structure, and which can be decentralized, despite traditional structures.

Fleury (2002) understands that the multiplicity of social actors involved in the political decision- 
making process would signal flourishing of a polycentric society, which privileges diversity and dialogue. This implies the production of trust, facilitating communication, negotiation and the construction of agreements which contemplate different interests. In this understanding, the author emphasizes that it is important to not only consider management, since this role can be simultaneously mediated by each actor or by a mediator who promotes communication between the actors in the network (Fleury, 2002). This structure causes changes in the understanding of politics as it recognizes the complexity of society and the State, considering the multiplicity of individuals. Based on the limitations and possibilities, Fleury (2002) points out the negative and positive aspects of networks in public policies:

Table 1: Characteristics of public policy networks.

\begin{tabular}{|l|l|}
\hline Positive aspects of networks & Negative aspects of networks \\
\hline $\begin{array}{l}\text { Greater mobilization of } \\
\text { resources (mainly human) and } \\
\text { diversity of opinions about the } \\
\text { problem. }\end{array}$ & $\begin{array}{l}\text { Challenges to ensure } \\
\text { accountability due to the } \\
\text { diversification of actors (public, } \\
\text { private, social). }\end{array}$ \\
\hline $\begin{array}{l}\text { Possibility of the presence of } \\
\text { the State in a non-bureaucratic } \\
\text { way. }\end{array}$ & $\begin{array}{l}\text { Difficulty in achieving goals, } \\
\text { given that the goals are diluted } \\
\text { among the actors in the network. }\end{array}$ \\
\hline $\begin{array}{l}\text { The establishment of adaptive } \\
\text { management connected to } \\
\text { social reality. }\end{array}$ & $\begin{array}{l}\text { Difficulty of coordination and } \\
\text { control. }\end{array}$ \\
\hline $\begin{array}{l}\text { Possibility of negotiation, } \\
\text { consensus, commitment and } \\
\text { responsibility which envision } \\
\text { aspirations for sustainability. }\end{array}$ & $\begin{array}{l}\text { Slow negotiation process to reach } \\
\text { mutual consensus. }\end{array}$ \\
\hline \multicolumn{2}{|l|}{ Source: Farias (2020) from Fleury (2002). } \\
\hline
\end{tabular}

From the understanding that networks reinforce an interaction and bond between individuals and groups, and are flexible according to the established involvement, it is understood that the network is a form of governance (Beaumont, Dredge, 2010), as it depends on skills and special competencies of each actor involved and share the same objective and resource available to achieve success (Coutinho; Nóbrega, 2019). In the case of tourism, political networks are presented as a possibility to expand participation in decisionmaking processes, whether in the traditional perspective that understands it as a marketing activity, or in collaborative networks which alternatively seek to meet social and environmental demands in tourism. Identifying the network promotes understanding of agents in the field of relationships, realizing how groups establish decisions and how they mobilize to participate in political actions (Table 2).
Table 2: Categories analyzed about networks.

\begin{tabular}{|l|l|l|}
\hline Category & $\begin{array}{l}\text { Author } \\
\text { /year }\end{array}$ & Conceptualization \\
\hline & $\begin{array}{l}\text { It makes it possible to understand the } \\
\text { bonds of people from different groups, } \\
\text { as well as reveals the limits and internal } \\
\text { structure of each group (among other } \\
\text { things). }\end{array}$ \\
\hline & $\begin{array}{l}\text { It reveals that public policies suffer } \\
\text { great interference from actors linked to } \\
\text { traditional institutions (such as political } \\
\text { parties and pressure groups), not to } \\
\text { mention the different social actors. }\end{array}$ \\
\hline & $\begin{array}{l}\text { Schneider } \\
\text { (2005) }\end{array}$ & $\begin{array}{l}\text { It understands that the network causes } \\
\text { changes in the political-administrative } \\
\text { structure, as it recognizes the } \\
\text { complexity of society and the State, } \\
\text { considering the diversification of } \\
\text { individuals included in the network } \\
\text { whose interests are multiple; it realizes } \\
\text { an increase in the actors involved, and } \\
\text { therefore the degree of uncertainty to } \\
\text { manage their relationships and their } \\
\text { results increases and opens paths for } \\
\text { new interpretations of public policies. }\end{array}$ \\
\hline $\begin{array}{l}\text { Understanding that different social } \\
\text { forms coexist in a society, and these } \\
\text { social processes and forms are mixed in } \\
\text { different places and periods of historical } \\
\text { transition, (re)constituting the network } \\
\text { society. }\end{array}$ \\
\hline
\end{tabular}

Source: Elaborated by the authors from Schneider (2005), Barnes (1987), Castells (2020) and Fleury (2002).

It is also understood that it is not only society that is diversifying its form of representation in the political field, but the traditional political institutions themselves, because they also (re)configure and (re)invent mechanisms and strategies to try to maintain the traditional power structure of coercion and social bargaining. The continuous reinforcement of social mobilizations and other forms of citizen participation in these disputes is important to accompany the evolution of the political field itself, although we know that "collective action is remarkably difficult for the relatively weaker and powerless" (Levi, 1991, p. 90) by the high concentration of power (political and symbolic) of the members of society who hold the political and social domains. For Nóbrega (2012, p. 133), the search for participation has the search for individual and/or collective interests in its conception, so it "is guided by some kind of relationship with power". According to Benevides' (1994) thinking, active citizens are valuable characters in the democratic process and need to be "created" and "organized" at all times from the multiplicity of spaces for deliberative discussion, expanding communication and information for effective political education from encouraging the creation of interaction networks. 
3. Experience in researching networks and tourism From an interdisciplinary perspective which presupposes scientifically constructing tourism with the interaction of other knowledge that involves the phenomenon, as highlighted by Barretto (2006), the objective of this study is to analyze the tourism network in Marajó, Pará, Brazil, in the context of regional tourism development ${ }^{2}$. Thus, we initially collected secondary information on the genesis and history of tourism processes in Marajó, in parallel with the understanding of the main local agents related to this practice in order to conduct the investigation on networks in the reported Region.

From identifying these contexts, documents were collected which expressed the public policy related to the theme explicitly about tourism or even dealing with the issue in a secondary or peripheral way. Information was collected in the field on the political forms in which it is possible to identify the performance of networks, such as the so-called "tourism governance bodies", including the Pará State Tourism Forum (Fórum Estadual de Turismo do Pará - FOMENTUR). An analysis of the Forum material was added to the information analysis available on Federal Government websites, such as the Transparency Portal and the Conventions' Portal (Portal da Transparência and the Portal de Convênios - SICONV and SIACOR, respectively), enabling an analysis of budget transfers directed to tourism in Marajó, PA. Although used in broader research for other purposes, this device appears in this section to identify the municipalities effectively related to the result of investments in the sector by the government at the federal level and from tourism policies and plans.

In addition, semi-structured, directive interviews were carried out throughout 2018 as a methodological strategy for compressing the performance of tourism networks in Marajó, with ancillary collection carried out until 2020 , enabling to establish connections between formal decisions and collective action strategies in the network. The choice of agents follows identifying members of instances such as the Forum, but also the traditional production chain, with representatives of the traditional trade and public agents, in addition to other agents which are part of the relational field of tourism, such as the Women's and Residents' Association of Vila do Pesqueiro
(Associação de Mulheres e Moradores da Vila do Pesqueiro).

Table 3: Agents interviewed in the Marajó tourism network in the municipalities of Soure and Salvaterra.

\begin{tabular}{|c|c|}
\hline \multirow{5}{*}{ 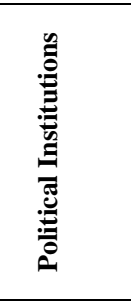 } & $\begin{array}{l}\text { Former Secretary of State for Tourism (Secretário de } \\
\text { Estado de Turismo - SETUR), who served until the } \\
2018 \text { term; }\end{array}$ \\
\hline & $\begin{array}{l}\text { Current State Interlocutor of the Pará Tourism } \\
\text { Regionalization Program }(2020)\end{array}$ \\
\hline & Soure Secretary of Tourism from 2018 to 2020 \\
\hline & $\begin{array}{l}\text { Tourismologist, servant of the Soure Municipal } \\
\text { Tourism Secretariat; }\end{array}$ \\
\hline & Secretary of Tourism of Salvaterra from 2018 to 2020. \\
\hline \multirow{3}{*}{ 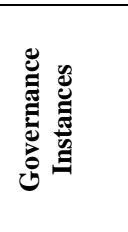 } & $\begin{array}{l}\text { President of the State of Pará Tourism Development } \\
\text { Forum (Fórum de Desenvolvimento Turístico do Estado } \\
\text { do Pará - FOMENTUR); }\end{array}$ \\
\hline & $\begin{array}{l}\text { President of the "Polo Marajó" Regional Tourism } \\
\text { Forum (Fórum Regional de Turismo do Polo Marajó - } \\
\text { FOREMAR); }\end{array}$ \\
\hline & President of the Soure Municipal Council of Tourism. \\
\hline \multirow{4}{*}{ 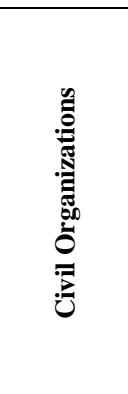 } & $\begin{array}{l}\text { President of the Marajó Tourism Association } \\
\text { (Associação de Turismo do Marajó - ATM); }\end{array}$ \\
\hline & $\begin{array}{l}\text { President of the Women's and Residents' Association } \\
\text { of Vila do Pesqueiro in Soure (Associação de Mulheres } \\
\text { e Moradores da Vila do Pesqueiro em Soure - } \\
\text { ASSUREMAS); }\end{array}$ \\
\hline & $\begin{array}{l}\text { President of the Vila de Joanes Rural and Artisanal } \\
\text { Educational Association (Associação Educativa Rural e } \\
\text { Artesanal da Vila de Joanes - AERAJ); }\end{array}$ \\
\hline & $\begin{array}{l}\text { President of the Association of Municipalities of the } \\
\text { Marajó Archipelago (Associação dos Municipios do } \\
\text { Arquipélago do Marajó - AMAM). }\end{array}$ \\
\hline $\begin{array}{l}\text { Private } \\
\text { iniciative }\end{array}$ & Businessmen from hotels and inns in Salvaterra. \\
\hline
\end{tabular}

Thus, the methodology was built to identify and analyze the performance of network actors in elaborating and implementing Tourism Policies aimed at Marajó; the concept of governance given the changes that have been directed by the National Tourism Policy; and the relationship between the network actions and the perception of its agents in the process.

\section{Analysis: Performance of Marajó Tourism Agents In Networks}

The Marajó region comprises sixteen municipalities, with a territory equivalent to $8.3 \%$ of Pará state $\left(102,810 \mathrm{~km}^{2}\right)$ and an estimated population of 577,790 inhabitants, corresponding to $6.5 \%$ of the state's total (FAPESPA, 2021; IBGE, 2021). Its geographic division is composed of three micro-regions: Arari; Furos de Breves and Portel. The first two are located at Marajó's most insular area (Marajó Island), which is known for being the largest fluvial-marine island in the world and the largest among those that form the Marajó

2 The work originates from an excerpt from the dissertation entitled "Governança do turismo na Ilha do Marajó - Pará: uma análise das redes de relações estabelecidas nas politicas públicas de turismo" (Farias, 2018). After the dissertation, the collection continued to update data in the process of preparing the doctoral qualification report and in the study for Rota Marajo of the project on Qualification in Tourism of the UNB/UFPA. 
Archipelago ${ }^{3}$, with $49,606 \mathrm{~km}^{2}$. It has a strategic geopolitical position for being within the notorious Marajoara Gulf ${ }^{4}$, on the boundary between the waters of Amazon River estuary and the Atlantic Ocean (Alves, 2016), and consists of 12 municipalities, including Soure and Salvaterra. Within the western part of Marajó the micro-region of Portel is found, which is composed of four municipalities and is predominantly continental.

Soure and Salvaterra occupy the 122th and 121th position, respectively, in the Gross Domestic Product (GDP) ranking of the State of Pará. The current Human Development Index (HDI) demonstrates the incipience of the municipalities of Marajó in terms of life expectancy, education and per capita income. The agricultural sector, services and administration and public services make up the largest share of the municipalities' gross domestic product, being: $17.24 \%, 25.71 \%$ and $49.65 \%$ respectively in the municipality of Soure; and $13.69 \%, 27.61 \%$ and $49.87 \%$ respectively in the municipality of Salvaterra (FAPESPA, 2021).

There is a great diversity of natural resources (fauna and flora) and geographic accidents in this region, which enable a unique and at the same time heterogeneous landscape. The cultural and social aspects refer to a historical trajectory marked by conflicts experienced by local residents in the 18th century and part of the 19th century, especially by traditional populations (indigenous communities, quilombolas, caboclos, riverside dwellers, etc.) in the municipalities of Soure and de Salvaterra, in an attempt to use and manage natural resources which are usually found on private properties.

The first public policies to guide tourism in the State of Pará began in the 1970s with research on the state's tourist conditions coordinated by the Pará Institute for Economic-Social Development (Instituto do Desenvolvimento Econômico-Social do Pará - IDESP). Tourism was even more encouraged during this period until the 1980s, presenting itself as "[...] an economic alternative capable of lifting the depressed economies of the northeastern states and of boosting the economy of the Amazon with the 'wave' of ecological tourism" (Rodrigues, 1996, p. 149). Marajó would then become a consolidated tourist destination in national operators headquartered in the center-south, with its sale associated with this type of tourism in the main product catalogs.

There was a boost to tourism development in the region with the stimulus to ecotourism on the Ilha do Marajó in the 1980s, especially in the municipalities of Soure and Salvaterra which included "Belém tourism agency, Soure hotels and two pioneer farms which offered demonstrations of milking and cart and horse rides" (Castro; Campos, 2015 , p. 463), and were able to stimulate rural tourism. A little later, especially in the early $2000 \mathrm{~s}$, there was a slowdown in tourist activity on the island, and local businessmen understand this period as a period of decadence.

\section{Marajó tourism agent activities in networks}

Public policy networks incorporate different actors, official or not, which differ in social and political subsectors. According to Castells (2005), this importance is improved in active democracy, recognized as an important mechanism in society's communication, and can be used as an instrument in an innovative policy. Thus, there is a representation of the tourism network to better visualize the actors who are directly or indirectly involved in the current political context of tourism in Soure and Salvaterra (Figure 1), which allows visualizing the actors as well as the interaction between them.

The representation and visualization of the network, its actors and their interactions enables a first look to understand the agents of the relational field and the interaction of these agents, also indicating the network dynamics in the same way. Although the network produces the field, agents can compose this field, but not necessarily be present in the network. The network presents its participants and they were identified from the dynamics they produce in their creation. Among the participants, all build perceptions about tourism, its relationships and the dynamics and actions for tourism to become more dynamic. Therefore, they produce several discourses on tourism and its effects, and regarding the theme of this investigation, they expose the perspective with which they understand their participation in the network and in decision-making processes, as explained in Tables 1 and 2 .

3 The Marajó Archipelago comprises approximately 2,500 islands, among the most important and habitable are: Marajó Island, Mexiana, Caviana, Porcos, Mututi and Uituquara (Amaral. et al., 2007).

4 The Marajoara Gulf "includes the wide mouth-bay of Amazon's River between Amapá and the extraordinary Marajó Island; Estreito de Breves is located to the west of this island, ending in the long stretches of Baia das Bocas; and to the east-northeast, the Pará River, the BaixoTocantins and the Marajó Bay. An essential sector in the history of the Amazon and its sub-regional peculiarities, where the nodal point of Belém do Pará, the nodal point of Macapá/Porto de Santana, the nodal point of Jari and the small nodal sector of the Breves region are identified (Ab'Sáber, 2010, p. 16). 
Figure 1: Tourism network in Ilha do Marajó.

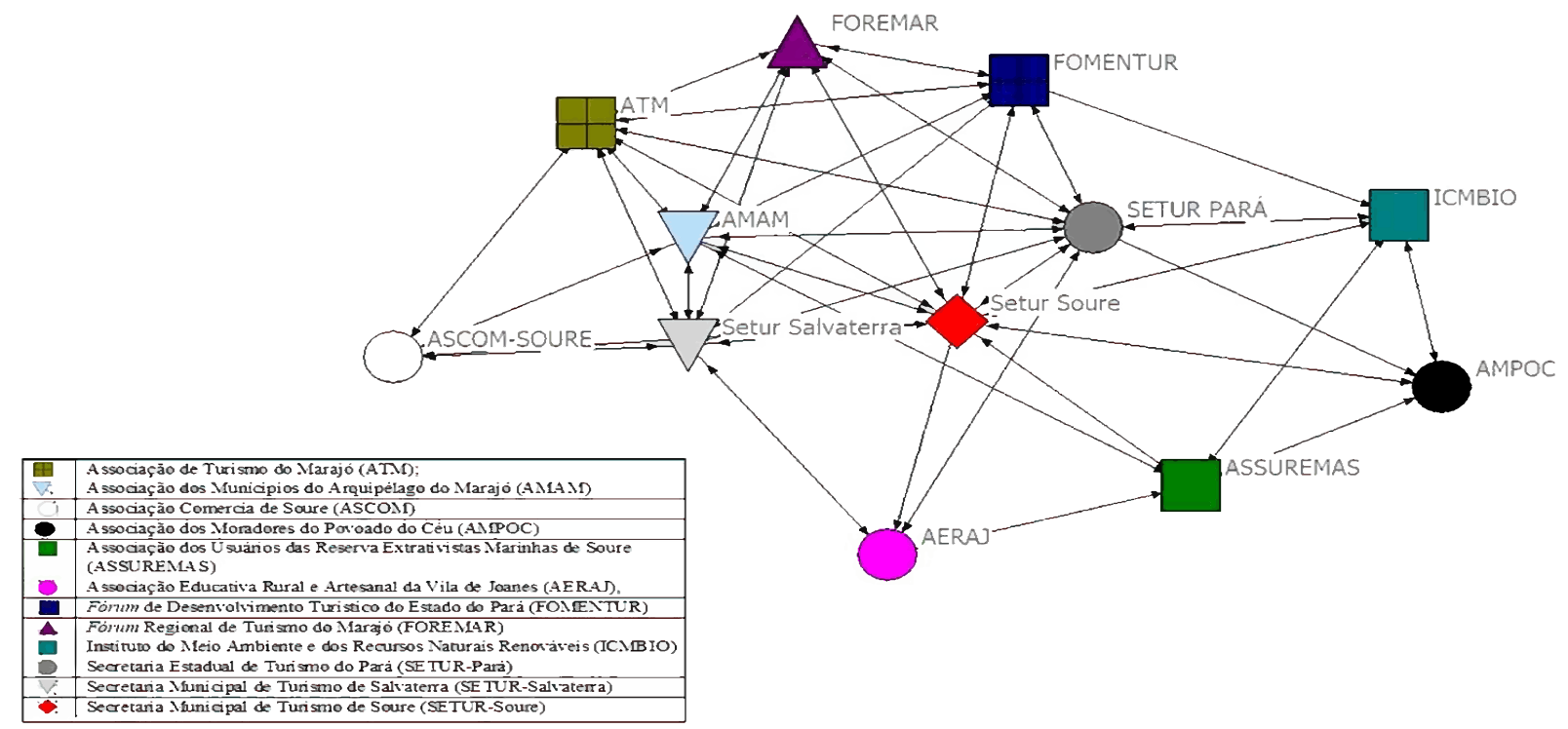

Source: Farias (2018).

Governments at the federal, state and municipal levels, companies and civil organizations that traditionally drive tourism networks need to be in harmony so that the work (together) functions minimally. This is the main feature of networks. The difficulties in putting its operation into practice are: 1) the interpretation that each agent has about the importance of the network's operation and mainly of tourism; and 2) the lack of communication between the different agents involved or not in this tourism dynamic. This is a necessary articulation for the different political channels to function, as well as for the very survival of the mechanisms of citizen participation.

The municipal tourism councils have been presented as an important institutional innovation among the governance instances created and induced by public policy at the federal level, which allow ensuring improved governance and its democratic role (Azevedo; Anastasia, 2002, Trindade et al., 2019). Thus, the tourism council acts decisively on the spot as a cooperation institution, as its function enables "mobilizing organized segments; networking the different local sectors; formulating local strategies for planning and developing tourist activity from a decentralized and articulated management" (Trindade et al. 2019, p. 660).

Da Mata, Pimentel and Emmendoerfer (2018) report that the creation of laws aimed at the creation of Municipal Councils in Brazil, such as the 1988 Constitution, the National Policy for Social Participation and the Social Participation
System, were fundamental to consolidate spaces for social participation in political processes in the state field. These normative acts gained their own contours in tourism with the creation of governance bodies in Brazilian regions and municipalities.

The results of decentralizing dynamics of tourism policies are directly related to the influence of the participating agents involved with the activity in decision-making processes. The network problems in relation to the common goals was noticed in this study, which are at the key of tourist development. Many components of the Marajó tourism network perceive limited positive results. This happens when the degree of involvement and communication between network members is compromised.

The non-participation, or limited participation, of agents makes the decentralization objectives unfeasible, as there is no way to decentralize actions and policies if there is no one to participate and assume roles and functions. No matter how hard it may be for a representative to achieve the objectives of the Forums or Councils, the demands of the municipalities and their citizens need to be part of the public policy agendas, and to do so communication by the network and knowledge of the network are necessary: "Therefore, one cannot understand Public Policy Networks without also understanding the relationship process established between tourism agents, which is mainly through communication" (FARIAS; BAHIA, 2019 p.146). 
In the case of Marajó, even though Soure and Salvaterra are priority municipalities in the State Policy, they have not yet managed to fully implement/create this important concept of participation. Soure then created the Municipal Tourism Council of Soure (Conselho Municipal de Turismo de Soure - COMTUR) with difficulties, but its actions and agendas cannot reach the "higher" scales of governance instances.

Regarding the interactions between network actors in the Marajó region, the data collected and presented in Figure 1 reveal that the centrality of input (Indegree), represented by the number of arrows that an actor receives within the network, is greater in the Soure Municipal Secretariat of Tourism (Secretaria Municipal de Turismo de Soure - SETUR-Soure) and in the Pará State Secretariat of Tourism (Secretaria Estadual de Turismo do Pará - SETUR-Pará). This fact reveals the importance and centrality of these two actors in the network, and indicates the need to create local governance bodies, meaning Municipal Tourism Councils, so that local actors, organized or not in collective actions such as associations, are able to participate in decisions made on tourism activity at the local level.

Although the municipal tourism councils reveal weaknesses, especially in the way decisions are made, as they delimit the participation in consultative processes, and may even reduce the autonomy of the actors, their relevance for the interaction and participation of different actors were observed, especially those representing organized civil society; the Residents' Association of Povoado do Céu (Associação dos Moradores do Povoado do Céu - AMPOC) and the Women's and Residents' Association of Pesqueiro (Associação das Mulheres e Moradores do Pesqueiro - ASMUPESQ) are in this situation. These organizations represent communities which are inserted in the Soure Marine Extractive Reserve area (Reserva Extrativista Marinha de Soure), and they are also represented by the Soure Users' Association of the Marine Extractive Reserves (Associação dos Usuários das Reservas Extrativistas Marinhas de Soure - ASSUREMAS)

Few local representations were detected with the absence of the Tourism Council in the municipality of Salvaterra. The exception was the Vila de Joanes Rural and Artisanal Educational Association (Associação Educativa Rural e Artesanal da Vila de Joanes - AERAJ), which has an important role in the district of Joanes for its cultural and social productions, which are directly linked to the tourist activity in the area. According to an interview with the Secretary of Culture, Sport and Tourism of Salvaterra (Secretário de Cultura, Esporte e Turismo de Salvaterra - SETUR-Salvaterra), there has already been an attempt to create a Tourism Council in the municipality; however, according to the respondent, political-partisan differences were the biggest impasse:

[...] the lack of integration due to the position of party politics. Some people are like that because they were very close in the previous administration or were benefited too much for some reason by the previous administration, then when we come here everyone is at the same level, and then what happens? For some other reason they were not benefited, and those who had benefited when they wanted to criticize excessively criticized... in short, they were the same problems of party politics (verbal information, interview given in January, 2018).

In this case, the interaction of SETUR-Salvaterra is greater with formal bodies, such as the Association of Municipalities of the Marajó Archipelago (Associação dos Municípios do Arquipélago do Marajó - $A M A M$ ), and up to 2019 with the Regional Forum of Marajó (Fórum Regional do Marajó - FOREMAR), than with the representations of society which demonstrates the fragility of creating political instruments capable of expanding participatory processes in developing tourism in the municipality.

The Association of Municipalities of the Marajó Archipelago $(A M A M)$ also plays an important role in the network, as it is the interlocutor of the municipalities of Marajó with the state governance organ FOMENTUR, and the regional organ $F O R E M A R$. However, considering the local context, interactions between $A M A M$ and society were not detected in the survey, as none of the interviewed actors (representatives of the communities of Soure and Salvaterra) knew about it.

It was observed that few actions have taken place since the creation of FOREMAR to increase civil society participation from the different municipalities of Marajó within the forum. A lack of communication and publicity of the actions carried out by FOREMAR were detected problems, considering that many actors in the network were unaware of the forum's role as a participatory channel of public policy for tourism in Marajó, such as the Vila de Joanes Rural and Artisanal Educational Association (AERAJ), the Women's Association of Pesqueiro (ASMUPESQ), and hotel businessmen, who claimed not to know about it. 
Therefore, in recognizing FOREMAR s limitations and operating difficulties, an election was held in 2017, decentralizing the Forum's actions to the two regions of Marajó. This made it possible for the Forum to elect a representative from Marajó dos Campos and another from Marajó das Florestas, who could be the president and vice-president. FOREMAR was only chaired by only one representative until 2017. Although the limitations presented were numerous, the regional Forum contributes to important actions, such as the improvement of river transport, the subject of numerous complaints.

[...] the Tourism Forum is very important for us to reach the municipalities, for us to be able to have a strong presence, so that not only AMAM, but so that we can have interlocutors; AMAM and the Forum are integrated so that we can have greater strength to dialogue with the State. The instance strengthens Marajo's struggle to develop tourism in the region (verbal information ${ }^{5}$ ).

The regional Forums were removed in a new administration of $S E T U R-P A$ in 2019 , as well as a reorganization of tourist regions, which from six tourist centers became 14 tourist regions in the state. The exclusion of regional forums weakened the process of establishing the network, which started in 2003, with the creation of FOMENTUR. The importance and participatory trajectory played by the regional Forums in the tourism network of Pará were not considered, as could be seen in the minutes of FOMENTUR meetings, as well as in the speech of the State Interlocutor of the SETUR-PA Tourism Regionalization Program:

Then, there is FOMENTUR, which is a State Tourism Forum, which brings together all the tourist trade and in which the 14 tourist regions are included, which are in the representation of FOMENTUR. The municipal councils are within the municipality only, for the time being. But they can also, depending on how the region is, be part of the IGR, they are already part of the Tourist Region, as the Municipal Council of Tourism, but they can also be part of the IGRs. But this is a criterion that is up to the tourist region, the group that is creating this IGR. With the reorganization, did SETUR think about changing the governance instances in the state of Pará? Did you even discuss this process, which would, in a certain way, have repercussions on existing governance bodies? No, because you see, the reorganization was in the tourist region. Many people today make the confusion of an
IGR with a tourist region. One thing has nothing to do with another. But in the discussion of the IGR, we have been raising awareness with the representatives of these regions, who may be putting together a group to form an IGR, but we have this awareness-raising in our regionalization workshops because it is not easy to create the IGR. It is already difficult for us to raise awareness of tourist activities in the city (verbal information ${ }^{6}$.

Another important player in the network, the Marajó Tourism Association (Associação de Turismo do Marajó - ATM), is composed of representatives from the Marajó private sector, such as hotels, transport companies, travel agencies and tour operators. This organization has gained prominence in the network by establishing relationships with SETUR-Pará, FOMETUR and the Municipal Tourism Secretariats of Soure and Salvaterra. This fact confirms the political and organizational strength of this association as a representative of the private sector on the Ilha do Marajó.

Other organizational forms of this sector in the municipalities in question are the associations of local traders, such as ASCOM-Soure. Its operation is aimed at organizing trade and service providers in the municipality. Thus, tourism is just one of the agendas dealt with by this association, which explains its little role in the tourism network in Marajó, as illustrated in Figure 1.

Thus, it is observed that the lack of knowledge of important channels for discussions and information exchange, such as the State Forum and the former Regional Tourism Forum, signal the difficulties and fragility of the decentralization process and participation in tourism in Marajó. This situation is illustrated in Table 4, with excerpts from the interviews of some representatives (public power, civil society and private initiative).

\footnotetext{
5 Interview conducted with the FOREMAR Representative in 2019.

6 Interview conducted with the State Interlocutor of the SETUR-PA Tourism Regionalization Program in February 2021.
} 
Table 4: Systematization of agents' perception of the Governance Organ (Forums and Councils).

\begin{tabular}{|c|c|}
\hline Interviewee & Perception of Governance Organs (Forums and Councils) \\
\hline $\begin{array}{l}\text { Secretary of State } \\
\text { for Tourism }\end{array}$ & $\begin{array}{l}\text { "The Forum works as a catalyst link between all agents who work and can contribute to tourism as an } \\
\text { economic activity in the State of Pará [...]. The Forum has its official participants, but it is an open } \\
\text { forum, any entity can participate, can invite themselves or can be invited by a representative of the } \\
\text { Forum to be present. So this is open. Now my understanding is that we still need to know how to better } \\
\text { use the Forum [...]. The score I would give it in its importance would be } 10 \text {, but in its result a } 6 \text {, due to } \\
\text { weak understanding of the tourism process as an economic activity [...]. As the various actors are more } \\
\text { planned to participate in the processes, they look for it and we look for them. This is a process which } \\
\text { occurs with a certain naturalness. Some are more active and others less, and this will depend on who is } \\
\text { conducting the entire process". }\end{array}$ \\
\hline $\begin{array}{l}\text { Soure Municipal } \\
\text { Secretary of } \\
\text { Tourism }\end{array}$ & $\begin{array}{l}\text { "FOREMAR went in the very oriented interest of the Soure and Salvaterra municipalities. Because it } \\
\text { was just there. The forum does not have resources to give subsidies to take to another municipality on } \\
\text { the other side of Marajó. [...] What structure do I give these forums to better develop their regions? None } \\
\text { [...] (This structure that you refer to and the economic, financial structure itself? It's the financial one, } \\
\text { because I'm in Belém, I'm in Soure, how do I get from here to Breves, Anajás, Gurupá, will I have to pay } \\
\text { for my own resources? Or will my institution have to pay? If it is an action that will help the Ministry to } \\
\text { develop Public Policies for my region [...] (how does the Municipal Tourism Department manage to } \\
\text { dialogue with these FORUMS, in this case FOREMAR?) It can't, in my opinion it can't, because I'm } \\
\text { going to be very honest, as a tourismologist, I still don't see this effective dialogue in my state, it's still } \\
\text { very loose, very mixed up, I'm not even managing to organize the bare minimum, so that the state works } \\
\text { in a regionally articulated way, I have to see each municipality [...] . So, how can I say that my region is } \\
\text { articulated if even the main municipalities which are recognized by the Ministry are not organized? [...]". }\end{array}$ \\
\hline $\begin{array}{l}\text { Tourismologist, } \\
\text { servant of the } \\
\text { Soure Municipal } \\
\text { Tourism } \\
\text { Secretariat }\end{array}$ & $\begin{array}{l}\text { "Nobody does tourism alone, everybody needs everybody. And, the Tourism Forum, when people come } \\
\text { together, they will necessarily be stronger. If I have a practical set, which I can't benefit from a part... } \\
\text { it's no use working today only as a means of accommodation [...] if I have bad transport, if I have bad } \\
\text { tourist attractions, if I have service providers bad services, hotels will be idle and the reverse too [...] } \\
\text { and tourism is a chain [...]. Today the people there (Soure) have already started to work for each other's } \\
\text { benefit. Agents were switched and most of the agents who joined have a fresh mind" [...] }\end{array}$ \\
\hline $\begin{array}{l}\text { Municipal } \\
\text { Secretary of } \\
\text { Salvaterra }\end{array}$ & $\begin{array}{l}\text { "I create expectations with this new FOREMAR management that we can achieve this objective of } \\
\text { having a participatory bias, but like the FOREMAR representative, he always had assiduous } \\
\text { participation, but he never had support, support from the segments that they could give sustainability } \\
\text { to their discussions and demands with FOMENTUR for benefits in the Marajo region, so that is to say } \\
\text { he was a solitary voice, speaking on behalf of the collective, speaking for the benefit of the collective.[...] } \\
\text { he kept the information for the municipality, for } A M A M \text {, but he had no counterpart, if a lot did not } \\
\text { happen through the FORUM, it was because there was no active participation of the members and } \\
\text { sustainability representatives who could give direction to the forum. (But were the discussions } \\
\text { established in the forum passed on to the municipalities?) They were, I can say yes in Salvaterra. (How } \\
\text { were they passed on to you?) Through the e-mail formation, it was passed on to the discussion minutes } \\
\text { and everything else, through that we manifested ourselves in making some progress and saying what } \\
\text { we were thinking about that discussion, finally we raised our position". }\end{array}$ \\
\hline $\begin{array}{l}\text { FOREMAR } \\
\text { president }\end{array}$ & $\begin{array}{l}\text { [...] if these representatives are not active, the thing goes blank. If you actually look at other } \\
\text { municipalities who are in this: "they don't speak". It's that story the deaf don't know what the mute } \\
\text { wants, so they have to talk, right? I believe that today, because you see, the economic activity of Marajó, } \\
\text { specifically in Soure, was cattle raising and fishing, today I believe that tourism is the third economic } \\
\text { activity, if not already the second. Today we have a Marajó Tourism Association that already fights for } \\
\text { our interests. This Association is perfectly replacing the Council, although the Council is reorganizing } \\
\text { itself as well. So these are the interests that we have to have as a representative of a certain entity in } \\
\text { the case of FOMENTUR, right? You have to have interests. There are two factors: the importance of } \\
\text { tourism and the interest represented by this instance (What are the difficulties of dialogue between } \\
\text { FOREMAR and FOMENTUR?) Look, we haven't had much difficulty, because whenever we need } \\
\text { something from the Tourism Department, we have one... we don't always get it, because I think that all } \\
\text { of us, in any circumstance, have limitations. So within the State Tourism Secretariat, what was possible } \\
\text { within the limitations of this Secretariat, we have arrived and posed the problems that they are solving } \\
\text { as much as possible. (Has the Forum/Council been active in the elaboration and implementation of } \\
\text { Policies aimed at the Polo do Marajó? What is your assessment of the Forum/Council's performance?) } \\
\text { Look, this is very related to PRODETUR. It's the kind of thing that doesn't depend on the Secretariat, } \\
\text { because if it depended on the Secretariat, it would have already been resolved. In the elaboration of the } \\
\text { PDITS, we had a very active participation in the elaboration of this Program, we as FOREMAR [...]" } \\
\text { (What is your assessment of FOREMAR's performance?) Look, despite everything, FOREMAR said what } \\
\text { it came for. At least it tried to resolve some situations. Some were resolved as in the case of transport, } \\
\text { others were not resolved exactly, such as PRODETUR. But what is certain is that it was present, in the }\end{array}$ \\
\hline
\end{tabular}


Journal of multidisciplinary academic tourism 2021, Special Issue 1: 53-67

\begin{tabular}{|c|c|}
\hline & $\begin{array}{l}\text { worst case FOREMAR was present with FOMENTUR. Maybe I don't even know if the whole community } \\
\text { knows about FOREMARs work, but the truth is that it tried to do something." }\end{array}$ \\
\hline $\begin{array}{l}\text { President of the } \\
\text { Marajó Tourism } \\
\text { Association }(A T M)\end{array}$ & $\begin{array}{l}\text { "As far as I know, the council is a consultative entity, so in practice it doesn't work, a process that } \\
\text { requires extra mobilization for the council to work, without this mobilization everything is on paper. We } \\
\text { realize that people participate, at the time of doing, they will do what the public administration wants } \\
\text { to do, so that's why I say it needs an action, a forum, so that it can get off the ground". }\end{array}$ \\
\hline $\begin{array}{l}\text { President of the } \\
\text { Women's and } \\
\text { Residents' } \\
\text { Association of the } \\
\text { Vila do Pesqueiro } \\
\text { in Soure } \\
(A S M U P E S Q)\end{array}$ & $\begin{array}{l}\text { "Yes, we participate in the Soure Tourism Council, in the municipality. (Have you been present at any } \\
\text { Council meeting?) Yes. I am a counselor (How do you perceive your participation in these tourism } \\
\text { discussions?) It is very important, right? for us to have community-based tourism here in the community } \\
(T B C) \text {. We are reactivating it (TBC) too, which was stopped, right? for a while there, for lack of } \\
\text { administration. So it worked so well for us that we're wanting it to happen again [...]. }\end{array}$ \\
\hline $\begin{array}{l}\text { President of the } \\
\text { AERAJ }\end{array}$ & $\begin{array}{l}\text { "Difficult, when they invite us and we go and participate, as long as we don't leave here, because we } \\
\text { can't leave here on our own unless they make it easy for us (Did they help?) No, for the forum, not for } \\
\text { these things. (Have you ever heard of FOREMAR and FOMENTUR?) No, never. (What about tourist } \\
\text { boards?) Here, for example, Silvia, the representative of the board of education. Tourism doesn't have } \\
\text { one". }\end{array}$ \\
\hline $\begin{array}{l}\text { President of the } \\
\qquad A M A M\end{array}$ & $\begin{array}{l}\text { "AMAM had a seat at the Forum even before the Regional Forum. We have already been part of } \\
\text { everything that is Council, Forum, everything related to the issue of tourism. Today, those who have a } \\
\text { seat are the governance bodies and not the association of municipalities, in fact, we were part of it } \\
\text { through } F A M E P \text {, because FAMEPhad a seat [...]. (Does FOMENTUR satisfy the wishes of Polo Marajó?) } \\
\text { I don't think so, I think FOMENTUR, no it doesn't... I think there is more for us to understand? Go } \\
\text { inside the Forum and argue, because you know right? that Forum and Council is a daily struggle. It's } \\
\text { for you to go there, set something up and fight for it to be contemplated, for it to be for the region. Until } \\
\text { then FOREMAR, as it was a Forum that discussed more the interests of two municipalities, then it } \\
\text { fought for those two. Today we have a context, you know?" }\end{array}$ \\
\hline $\begin{array}{l}\text { Business owners of } \\
\text { hotels and inns in } \\
\text { Salvaterra }\end{array}$ & $\begin{array}{l}\text { "Look, we've already participated in some here, but it's just that they don't have an active frequency, } \\
\text { like, in the city, right? they come, do those things and leave, but it's not sustainable (When you say they, } \\
\text { who does "they" refer to who?); "to the people who do tourism in the city, right?" (Hotel } 1 \text { verbal } \\
\text { information). } \\
\text { "I have Knowledge (Have you ever attended a Forum or Council meeting?) no. I only know that these } \\
\text { organs exist. I have so much frustration with these organs, you know? There's so much talk and little } \\
\text { result, I'm a little skeptical of these organs" (Hotel } 2 \text { verbal information). }\end{array}$ \\
\hline
\end{tabular}

In this context, the intended decentralization does not only refer to the possibility of directing political decisions to civil society, necessarily requiring a dialogue between the different actors - public power, private sector and civil society. For these measures to be implemented in the governmental field, "radical changes in the way of governing are needed, promoting a more solidary and participatory social and political regulation [...]" in public spaces (Caccia-Bava, 2001, p. 75). Citizen participation in decision-making processes has been particularly insufficient in Marajó, and when it happens, it is sometimes restricted to bureaucratic issues.

Another problem arises: the studies by Castells (2005) on the formation of networks demonstrate that the key to interpreting this category does not necessarily involve articulations in favor of solutions for productive arrangements or productive chains. The association between productive arrangements and chains in tourism and the development of tourism, public policy and participation networks and even the understanding of tourism governance, with the presence of the so-called "governance organs" is very present, and the agents often take turns between market agents and public agents (Figueiredo, Nóbrega, 2015).

As highlighted by Beni and Cury (2012), work articulated in networks refers to new organizational and production possibilities in the globalized world. This perspective in tourism would promote partnerships, co-management and associated management with the objective of regional development and tourism development; in addition, it would reinforce the idea that the "common strategy planned by the network partners can result in new priorities and new combinations of cooperative production, and vital 
permanent feedback dynamics for consolidating tourism clusters" (Beni; Cury, 2012, p.488).

New social and organizational dynamics from this framework have absorbed the tourist activity in an autonomous way as a possibility of social reproduction, as traditional groups and communities. These groups are beginning to establish themselves as component actors of tourism networks, although the domain of the economic perspective in public policies and activity planning is recognized. They have been contributing little by little to the structuring of networks based on the decentralization of information and processes between different social agents, which directly or indirectly dynamize the tourist activity and transform it.

To get an idea of the resources transferred by the Ministry of Tourism (MTUR) to the municipalities that make up the Marajó region, only the municipality of Soure obtained a transfer of funds to a civil society organization in 2018, namely the Women's and Residents' Association of Vila do Pesqueiro in Soure (ASMUPESQ). $A S M U P E S Q$ is an organization created and located in a Conservation Unit in the Extractive Reserve category (RESEX - Marinha de Soure), coordinated by women who develop actions directly linked to environmental and sociocultural issues in their territory. This organization has been developing community-based tourism practices since 2005 , with the objective to carry out tourism in an autonomous and decentralized manner.

The situation of ASMUPESQ is paradigmatic in this study, because although it is representative of an important community located in the main tourist attraction of Marajó, it has not been a participant in the Tourism Planning of the State of Pará, as noted by the president of ASMUPESQ:

[...] we only participate in the Council, but there is no other like... other activity, you know? That involves us directly. (Have you ever heard of the Cheese Route?) Yes, we were never invited to participate. We know it's the SETUR people and everything, who are so involved, you know? But we were never invited, so to participate in a conversation with them, nothing. (Who participates?) Only the people from the municipality, they only invite the entrepreneur, right? the big businessmen (verbal information, our emphasis).

The lack of knowledge of important channels for discussions and information exchange, such as the State and Regional Forum in the state of Pará represented by FOMENTUR, makes it impossible to maintain and even create new networks which allow democratic discussion of proposals to develop tourism in the area (Figueiredo; Nóbrega, 2015). These articulations are necessary for the functioning of the different political channels, as well as for the very survival of citizen participation mechanisms in the public arena in a decentralized manner.

Public policies aimed at tourism in Brazil since the 1990s have dynamized strengthening the leading role of the tourism production chain at regional and local levels. Including different agents in the decentralized management process in these has been encouraged through the creation of institutions such as those created in 2003, with the Tourism Regionalization Program - Brazil Routes (Programa de Regionalização do Turismo - Roteiros do Brasil - PRT): Municipal Councils, Regional Forums, State Forums, National Tourism Council (Conselho Nacional de Turismo - CNTUR), the National Forum of State Secretaries and Directors of Tourism (Fórum Nacional de Secretários e Dirigentes Estaduais de Turismo - FORNATUR).

ASMUPESQ is highlighted by proposing the application of a new tourism concept, aimed and carried out for and by the community in one of the main tourist attractions in the municipality of Soure. However, as observed in the structure of the governance organs created in the state of Pará, this organization has a limited role and is only inserted in the debate process of the municipality when it participates in a consultative manner in the Municipal Council of Tourism of Soure (Conselho Municipal de Turismo de Soure-COMTUR-Soure), but is unable to participate in the Regional Tourism Forum of Marajó (FOREMAR), nor does it participate or is even aware of the State Tourism Forum

However, there was a reorganization of the tourist regions of the state with the restructuring of the State of Pará Tourism Department into a new political mandate of the state government started in 2019, being previously divided into six tourist centers and now 14 tourist regions in the current context. This reorganization changed the structure of the regional tourism Forums, considering that each Forum was created based on the old order, meaning that there was a regional forum for each tourist pole. In accordance with what can be analyzed in the minutes of FOMENTUR meetings (2019 and 2020) and in an interview with the State Interlocutor of the Tourism Regionalization Program in early 2021, the Regional Forums were removed and the new guidelines of the national tourism policy, such as the creation of Regional 
Governance Organs (Instâncias de Governança Regionais - IGRS) in the state of Pará.

The proposal for institutionalization of organs was resumed under the government of Jair Messias Bolsonaro in 2019, reinforcing the need for constitution and institutionalization so that the articulation of tourism development strategies comes from "a more professional management process, without giving up on strengthening social participation" (BRASIL, 2019, p.22). The institutionalization of the Governance Organs, or $I G R$ (a term proposed in the current government), becomes something necessary, so it therefore requires greater commitment and convergence of agents for the change process with an executive focus.

Thus, public management advisory instruments in formulating and conducting public tourism policies in the municipalities and regions of Pará still have little meaning in their operation, since governance bodies are only recognized as a way of organizing tourism management. One more problem arises: the true objectives of these social forms in decisionmaking processes in the public arena, which refer to the possibility of expanding social participation and the diversification of actors in the mold of Teixeira (2002), and the flexible and dynamic decentralization of political decisions seem to be placed in the background in the search for the insistent objective of tourist development in the municipality, in other words, the market agents.

\section{Conclusion}

The recent changes in society, the reformulation of the State and the new dynamics of companies facing technological and social changes have been challenges in the new century, especially with the increase in political and economic crises, with the difficulties in representative democracy and in worsening the situation of precarious populations in the world. In this interface, new public policy and planning proposals are (re)configured in relation to the demands of the globalized world. Society has been transforming and organizations are increasingly flexible and adaptable to these changes, putting more traditional structures at risk.

Tourism as an economic activity under this parameter has also undergone intense changes in its dynamics and concept. It is linked to local and global changes, such as the conception of the State, the conduct of public policies, the expansion of participatory processes in governmental instruments and environmental changes, and
Tourism development has progressively interpreted these changes in its conduct.

Decentralization and the effective participation of different agents in the decision-making process of tourism do not disregard the presence of the State, and the importance of each institution representing society cannot be overemphasized. Therefore, thinking about the relations of tourist activity is inevitably thinking about the importance of the State and civil society agents beyond market agents.

The tourism network concept was initially signaled by encouraging creation of participatory channels in the municipalities, and the creation of Municipal Tourism Councils was encouraged to increase the autonomy of municipalities and the participation of society in political decisions. However, the political and social culture of many municipalities became the main obstacle to its realization, since these municipalities and their managers were not prepared to decentralize their decisions, nor was civil society prepared to make dynamic decisions that represented a set.

Although these instances are initiatives which enabled creating roles within the scope of participation, operational weaknesses and limitations were observed in Marajó. This is because many civil organizations, such as AERAJ and ASMUPESQ, are unaware of the existence and importance of these institutional channels at the regional and state levels, or are still unable to participate and interfere in important decisions, even as part of the network.

The influences of the networks of relationships established within the scope of public tourism policies, as well as their repercussions for the governance process in the municipalities of Salvaterra and Soure in the Marajó Archipelago, can be understood under different spectrums, but mainly the possibility of transforming traditional local political structures. These structures have marked the historical trajectory in Marajó from the conquest and occupation process by the Portuguese to the formation of local social relations. These relationships are mainly characterized by the resistance of local residents, especially by the traditional populations of Soure and Salvaterra, as shown by Marin and Silva (2007), who despite the economic, social and political powers which have established themselves there, have supported intense territorial processes and social struggles.

One of the difficulties encountered was the recent changes in the structure of the Pará's governance 
organ which significantly altered the tourism network in Marajó and other tourist regions. The new order brought with it the extinction of the Regional Tourism Forums, which functioned as a forum for discussion in each tourist pole under the pretext of adapting to the "new" premises of the PRT. In addition, there is a new political context for tourism in Brazil, which reinforces the creation of Regional Governance Organs (IGRs) with legal and financial autonomy, so that management becomes more professional. Thus, a new study is suggested which can analyze the consequences of participation in the tourism network in Pará, examining whether the institutionalization of IGRs accounts for the plurality and dynamics of agents in the tourism network.

\section{References}

Ab'Sáber, A. N. (2010). Zoneamento fisiográfico e ecológico do espaço total da Amazônia Brasileira. estudos avançados, 24, 15-24.

Amaral, D. D. D., Vieira, I. C. G., Salomão, R. P., Almeida, S. S., Silva, J. B. F., Costa Neto, S. V., ... \& Bastos, M. N. C. (2007). Campos e florestas das bacias dos rios Atuá e Anajás, Ilha do Marajó. Belém. Museu Paraense Emílio Goeldi, Belém.

Barretto, M. (2006). Turismo, cultura e sociedade. Caxias do Sul, RS: EDUCS. P. 7-10.

Barnes, J. A. (1987). Redes sociais e processos político. In: Feldman-Bianco, B. (Org). Antropologia das sociedades contemporâneas: Métodos. São Paulo: Global.

Baggio, R., Scott, N. \& Cooper, C. (2010). Network Science: A Review Focused on Tourism. Annals of Tourism Research 37 802-827.

BRASIL. (2019). Ministério do Turismo. Regionalização: institucionalização da Instância de governança regional. Brasília.

Benevides, M. V. (1994). Democracia e cidadania. In: Villas-Bôas, R. (Org.). Participação popular nos governos locais. São Paulo: Pólis.

Beaumont, N., \& Dredge, D. (2010). Local tourism governance: A comparison of three network approaches. Journal of sustainable tourism, 18(1), 7-28.

Beni, M. C., \& Cury, M. J. F. (2012). Bases territoriais e redes do cluster de turismo. In: Beni, M. C. (Org). Turismo: planejamento estratégico e capacidade de gestão - desenvolvimento regional, rede de produção e clusters. Barueri, SP: Manole, p. 487516.

Caccia-Bava, S. (2001). Participação, representação e novas formas de diálogo. São Paulo: Instituto Pólis.
Castells, M. A. (2020). A sociedade em rede. São Paulo:Paz e Terra.

Castells, M. A. (2019). O poder da comunicação. $4^{\circ}$ ed. São Paulo/ Rio de Janeiro: Paz e Terra.

Castells, M. (2005). A sociedade em rede: do conhecimento à política. A sociedade em rede: do conhecimento à acção política, 17-30. Belém: Imprensa Nacional.

Castro, E., \& Campos, I. (2015). Formação socioeconômica do Estado do Pará. In: CASTRO, E.; CAMPOS, I. (Orgs). Formação socioeconômica da Amazônia. Belém: NAEA,. p. 401-482.

Coutinho, A. C. A., \& Nóbrega, W. R. D. M. (2019). Governança em destinos turísticos: desafios na sociedade contemporânea. Revista Brasileira de Pesquisa em Turismo, 13(3), 55-70.

da Mata, G. M. F., Pimentel, T. D., \& Emmendoerfer, M. L. (2018). Teoria do campo social e políticas públicas: o caso do Conselho Gestor de Turismo de Juiz de Fora, MG, Brasil. Revista Rosa dos Ventos Turismo e Hospitalidade 10(2).

Enne, A. L. S. (2004). Conceito de rede e as sociedades contemporâneas. Comunicação \& Informação, $7(2), 264-273$.

FAPESPA. (2021). Fundação Amazônia de Amparo a Estudos e Pesquisa. Região de Integração do Marajó: Perfil socioeconômico e ambiental. Belém: FAPESPA- PA. Disponível em: http://www.fapespa.pa.gov.br/produto/diagnostic os/277. Acesso em 15 de set.

Farias, K., S, S. \& Figueiredo, S. L. (2015). Políticas públicas e turismo: avaliação da participação e das instâncias de governança em Abaetetuba (Pará-Brasil). Turismo \& Sociedade. Curitiba, 8 (3), 575-600. DOI: http://dx.doi.org/10.5380/tes.v8i3.41832

Farias, K. S. S., (2018). Governança do turismo na Ilha do Marajó - Pará: uma análise das redes de relações estabelecidas nas políticas públicas de turismo. Dissertação de mestrado. Núcleo de Altos Estudos Amazônicos, Universidade Federal do Pará, Belém.

Farias, K. S. S. \& Bahia, M. C. (2019). Processos participativos para o estabelecimento de uma rede de turismo no Marajó-Pará-Brasil: uma análise sobre a atuação do fórum regional de turismo do marajó (FOREMAR). In: Baptista, M. M., Pereira, M. J. A., \& de Almeida, A. R. A. (Org) Ócios e resistências: crescer e envelhecer em contextos culturais diversos. Coimbra: Grácio Editor.

Fleury, S. (2002). Redes de políticas: novos desafios para a gestão pública. Administração em Diálogo, São Paulo, no 7, pp. 77-89.

Figueiredo, S. L. (1999). Ecoturismo, festas e rituais na Amazônia. Belém: NAEA. 
Figueiredo, S. L., \& Nóbrega, W. R. M. (2015). Turismo e desenvolvimento regional: conceitos e políticas em um caso brasileiro. In: Figueiredo, S. L; Azevedo, F. F de; Nóbrega, W. R. M (Org). Perspectivas contemporânea de análise em turismo. Belém: NAEA/UFPA.

Gohn, M. G. (2013). Movimentos sociais e redes de mobilizações civis no Brasil contemporâneo. 7. Ed. Petrópolis, RJ. Editora Vozes Limitada.

Alves, F. O. (2016). A função socioambiental do patrimônio da União na Amazônia.. p. 107-198.

IBGE. (2021). Instituto Brasileiro de Geografia e Estatística: Cidades e Estados do Brasil. BrasíliaDF. Disponível em https://cidades.ibge.gov.br/. Acesso em: 10 jun.

Haesbaert, R. O. (2019). Mito da desterritorialização: do "fim dos territórios" à multiterritorialidade. $11^{\circ}$ ed. Rio de Janeiro: Bertrand Brasil.

Levi, M. (1991). Uma lógica da mudança Institucional. Revista dados, Rio de Janeiro, 34 (1), 77-99.

Marin, R. E. A., \& Silva, C. N. (2007). Os quilombolas de Salvaterra, Ilha do Marajó: processos de territorialização e acesso ao recursos naturais. In: Aragón, L. E. (Org). População e Meio Ambiente na Pan-Amazônia. Belém: UFPA/NAEA,

Nascimento, V. L. Q. (2015). Políticas públicas de turismo na Amazônia brasileira: sua ascensão às agendas do Amazonas e do Pará. Tese de Doutorado. Universidade Federal do Pará, Núcleo de Altos Estudos Amazônicos, Programa de PósGraduação em Desenvolvimento Sustentável do Trópico Úmido, Belém.

Nóbrega, W. R. M. (2012). Turismo e políticas públicas na Amazônia brasileira: instâncias de governança e desenvolvimento nos municípios de Santarém e Belterra, oeste do estado do Pará. Tese de Doutorado. Universidade Federal do Pará, Núcleo de Altos Estudos Amazônicos, Belém.

Nóbrega, W. R. M., \& Figueiredo, S. L. (2014) Turismo e gestão pública: uma avaliação das instâncias de governança no Oeste do Estado do Pará. In: Pimentel, T. D.; Emmendoerfer, M. L.; Tomazzoni, E. L. (Org.). Gestão Pública do Turismo no Brasil: Teorias, Metodologias e Aplicações. 1ed. Caxias do Sul: EDUCS. p. 425449.

Rodrigues, A. A. B. (1996). Turismo e geografia: reflexões teóricas e enfoques regionais. São Paulo: HUCITEC.

Schneider, V. (2005). Redes de políticas públicas e a condução de sociedades complexas. Revista Civitas, Porto Alegre, 5 (1) 29-58.

Trindade, B. S., César, P. A. B., \& Vianna, S. L. G. (2019). Governança do Turismo: planejamento e gestão local e regional em Gramado-RS, Brasil. Rosa dos
Ventos - Turismo e Hospitalidade, 11(3), p.653663, jul-set

Wray, M. (2009). Policy communities, networks and issue cycles in tourism destination systems, Journal of Sustainable Tourism, 17:6, 673-690 
2021, SP (1): 53-67

https://doi.org/10.31822/jomat.2021-SP-1-53

\title{
INFO PAGE
}

\section{Public tourism policies in the Brazilian Amazon: Participation and networks}

\begin{abstract}
The aim of this study is to analyze the tourism network in Marajó, PA, Brazil. To do so, we sought to elucidate the concept of participation, networks and public policies so that the mechanisms of their organization in this region can be understood. This work is an excerpt from the dissertation entitled "Tourism governance on Ilha do Marajó, Pará, Brazil: An analysis of the relationship networks established in public tourism policies" (Farias, 2018). This analysis uses an interdisciplinary approach in tourism, seeking to interpret it from theoretical perspectives on participation in public policies. The study follows several steps which in the end could be connected and interpreted based on the assumptions of qualitative research. The bibliographical deepening, documentary analysis, the elaboration and application of semi-structured interviews directed the study to reach the proposed objective. Thus, the analysis revealed that the participation of agents in the decision-making process in tourism does not aim to disregard the State, but seeks to confirm the importance that institutions represent. Some examples are civil initiatives and organizations such as the Women's Association of Pesqueiro (Associação das Mulheres do Pesqueiro - ASMUPESQ), as evidenced in the study.
\end{abstract}

Keywords: Tourism, Public Policy, Participation

\section{Authors}

\begin{tabular}{ccc}
\hline Full Name & Author contribution roles & Contribution rate \\
\hline Kassia Suelen Farias: Conceptualization, Methodology, Writing - Original Draft, Writing - Review \& Editing, Supervision, & $60 \%$ \\
\hline Silvio Lima Figueiredo: Conceptualization, Methodology, Writing - Original Draft, Writing - Review \& Editing, & $40 \%$ \\
\hline
\end{tabular}

Author statement: Author(s) declare(s) that All procedures performed in studies involving human participants were in accordance with the ethical standards of the institutional and/or national research committee and with the 1964 Helsinki declaration and its later amendments or comparable ethical standards. Declaration of Conflicting Interests: The author(s) declared no potential conflicts of interest with respect to the research, authorship, and/or publication of this article 